\title{
Effect of Anaerobic Fermentation Temperature on Three Different Types of Low-Grade Saudi Dates for Producing Ethanol Fuel Alashmawe, N. ${ }^{1}$; K. Ehmed ${ }^{1}$; M. Younis ${ }^{1}$ and A. Alhamdan ${ }^{2}$ \\ ${ }^{1}$ Agric. Eng. Res. Inst., Agric. Research Center, Giza, Egypt \\ ${ }^{2}$ College of Food \& Agricultural Sciences; King Saud University; Riyadh 11451; Saudi Arabia \\ "Corresponding author < Tel.: +966546657345; E-mail: nalashmawe @ksu.edu.sa>
}

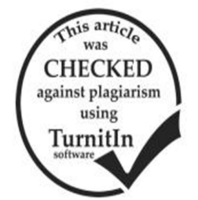

\section{ABSTRACT}

The present work aims to study the effect of anaerobic fermentation temperature on the production of ethanol fuel for three different types of sugar compositions in dates that commonly produced in Saudi Arabia. The fermentation temperature is considered as the most important factors affecting the production of ethanol. The obtained data referred that the ethanol yields from Sukkari dates were $107.6 \mathrm{~cm}^{3} \mathrm{~L}^{-1}$ juice, $123.3 \mathrm{~cm}^{3} \mathrm{~L}^{-1}$ juice, and $96.6 \mathrm{~cm}^{3} \mathrm{~L}^{-1}$ juice, during anaerobic fermentation temperatures of $30^{\circ} \mathrm{C}, 35^{\circ} \mathrm{C}$, and $40^{\circ} \mathrm{C}$, respectively. Whilst, the ethanol yields from Khlass dates were $111.0 \mathrm{~cm}^{3} \mathrm{~L}^{-1}$ juice, $122.0 \mathrm{~cm}^{3} \mathrm{~L}^{-1}$ juice and $128.0 \mathrm{~cm}^{3} \mathrm{~L}^{-1}$ juice during the same fermentation temperatures. Ultimately, the Berhi dates produced $121.0 \mathrm{~cm}^{3} \mathrm{~L}^{-1}$ juice, $136.0 \mathrm{~cm}^{3}$ $\mathrm{L}^{-1}$ juice, and $136.0 \mathrm{~cm}^{3} \mathrm{~L}^{-1}$ juice, under the same fermentation temperatures. The obtained results showed that the production of ethanol would directly proportional to the ratio of glucose and fructose composition in dates.

Keywords: Dates, Fermentation, Sugar, glucose and fructose

\section{INTRODUCTION}

Ethanol is a natural solvent combined with water and is called "Bioethanol" after its production through a fermentation procedure utilizing microorganisms. Transformation of sugars into ethanol is one of the most common anaerobic natural responses utilized by humankind (Benarji and Ayyanna, 2016). Ethanol can be made either artificially from petrochemical crude materials or naturally by the fermentation of sugar. When pure ethanol is produced from glucose or normal source by fermentation using distillation, the outcome is bioethanol. Bioethanol can be described as an inexhaustible and pure fuel for vehicles. However, it is typically utilized as a gasoline additive to raise the value of octane and enhance vehicle discharges.

Ethanol/bioethanol is an alcoholic transparent fluid that can be utilized as a raw material for derivatives of alcohol, in the synthetic industry, paint base industry, pharmaceutical industry, a blend of fuel for vehicles, that given the ethanol/bioethanol as a source of renewable energy to reduce the environmental pollution that occur from internal combustion engines. A $90-96 \%$ can be utilized in business and the industry, while ethanol having $96-99.5 \%$ can be utilized as a blend for fundamental modern materials and pharmaceuticals (Ghanim, 2013). Nowadays, the whole world countries have been taken the bioethanol as the most utilized biofuel instead of the fossil fuel. It is commonly created from sugar containing different farming productions eg., (sugar cane, corn, wheat, sugar beet, squander from sugar cane, or sweet sorghum). The dominating innovation for changing biomass to ethanol is the fermentation as a biochemical innovation (Prasad et al., 2007).

Bioethanol is broadly investigated as a sustainable fuel source because of the numerous contemplations it is better than gasoline. Ethanol gives vitality of unlimited and less carbon in the gravity than oil (Jones et al., 1994 ; Fakruddin et al., 2013). Ethanol is an important chemical with excellent potential as a biofuel to replace petroleum derivatives (Ghassem et al., 2012). Generation of ethanol from inexhaustible starchy materials has been drawing worldwide interest and research has been conducted for the creation of ethanol by immobilized microorganisms, through the utilization of consistent cultures (Goksungur, 2001). It is an essential natural compound utilized as a solvent in research work, businesses, and family units. Naturally, the utilization of ethanol as a substitute fuel has acquired much attention as an answer to some issues caused by gasoline from exhaustible oil reserves. It is created from different substrates, such as saccharides, starches, and cellulose materials. Accumulation of appropriate and commercially available substrates is an imperative cost consideration for the manufacture of ethanol (Hagerdal et al., 2006; Pinheiro et al., 2008; Srinivasarao et al., 2013).

Among biofuels, ethanol has extraordinary demand as it is widely acknowledged and it is ideal consumer. In many nations, ethanol is either utilized as a substitute fuel or mixed with petroleum or gasoline. Numerous specialists have contemplated on the generation of ethanol utilizing different raw materials. Organic product wastes such as papaya, mangoes (Reddy and Reddy, 2007), banana peels (Joshi,2001), pineapple (Muttamara et al., 1982), and grapes (Pramanik and Kinetic, 2005; Asli, 2010) were utilized for the manufacture of ethanol (Raikar, 2012). Technically, ethanol can be produced from a wide assortment of sustainable feedstock, which can be generally characterized into three primary categories; Firstly, those containing excessive amounts of promptly fermentable sugars (sweet sorghum, sugar beets, and sugar cane), secondly, starches and fructosans (corn, potatoes, rice, wheat, and agave), and thirdly, cellulosics (Stover, grasses, corncobs, wood, sugar reeds bagasse). Sugar reeds, beet, and sweet sorghum preserve the simple sugars such as sucrose, glucose, and fructose that can be promptly matured by yeasts (Amorim et al., 2009; Basso et al., 2011). Yeast and other similar microorganisms are normally utilized for the production of ethanol. Usually saccharomyces cerevisiae strains are utilized for the generation of ethanol.

Temperature is one of the most vital elements that influence ethanol generation by yeast utilizing molasses as a carbon source. The fermentation procedure is constantly accompanied with the development of warmth that raises the temperature of the fermenter (Jones et al., 1994). Ethanol maturation at upgraded temperatures is a principle need for successful ethanol generation in tropical districts where ordinary daytime temperatures are commonly high everywhere throughout the year. The rewards of fast fermentation at optimal level of temperature were not only the danger of pollution regardless likewise diminishes the cooling costs. To accomplish upgraded temperature aging it is necessary to utilize a suitable yeast strain that can endure high temperature (Limtong et al., 2007). For the bioethanol creation at higher temperatures, yeast cells die resulting in reduction in ethanol yield when the substrate is 
concentrated, while the optimum temperature giving the best yield is $32^{\circ} \mathrm{C}$ for the most extreme strains. Therefore, it is important to choose the optimal level of temperature for anaerobic fermentation (Edgardo et al., 2008; Yah et al., 2010). Considering the strains for temperature variations, there is a need for thermo-tolerant strains that can withstand high temperatures in the experiments. For instance, K. Marxian's DMKU3-1042 is considered to have an ideal temperature of $40^{\circ} \mathrm{C}$ (Abdel-Banat, 2010). Moreover, since at $45^{\circ} \mathrm{C}$ no development was seen and no maturation was observed, it was inferred that $\mathrm{S}$. cerevisiae have a range from $30-35{ }^{\circ} \mathrm{C}$, which is known to be ideal for fermentation (Bollók et al.,2000; Lin and Tanaka, 2006). Hence, temperature plays an important role. The dependence of the maximum ethanol production rate on the temperature was clarified by the superposition of initiation vitality for ethanol generation (Sánchez et al., 2004; Gorsek and Zajsek, 2010). Thus, at an optimal level of temperature to the yeast acquires a higher ethanol production.

Dates, as a natural product, are a reasonable source for bioethanol production. They contain impressive amounts of transformed sugars (glucose and fructose); the two sugars are available in dates in a practically comparable amount. The fresh of dates contains around 70 to $75 \%$ sugars (Elleuch et al., 2008). Low-grade dates demonstrated a similar sugar as dates of high grade (Besbes et al., 2009). Maturation of sugars is an anaerobic natural process in which sugars are converted into ethanol by the activity of microorganisms, such as yeast (Demirbas, 2007). Saccharomyces cerevisiae is the most prominent modern microorganism utilized for sugar fermentation to create bioethanol, because it uses simple materials for growth and generation. This organism has already been accepted as a non-pathogenic, safe product that can easily be genetically manipulated and on simple and inexpensive media as compared with animal cell culture (Vrsalovic and VasicRacki, 2005). Low-quality dates are rich in sugars, mostly glucose and fructose, which can be converted into ethanol and can likewise source of basic carbon for yeast development. Different supplements, minerals, and vitamins are additionally present in dates, which enhance the maturation procedure to create bioethanol. Many factor, such as temperature and starting sugar fixations, can influence the entire procedure. The $\mathrm{pH}$ within a suitable range appeared to have minor effect on bioethanol generation. Ethanol yields $>71 \%$ were obtained in controlled and uncontrolled $\mathrm{pH}$ tests. Ethanol yields of $91.3 \%, 68.7 \%$, and $54.8 \%$ were obtained from $10 \%, 15 \%$, and $20 \%$ starting sugar fixations, respectively. The decrease in ethanol production in the higher sugar ratios could be due to the Inhibition of sugar for ethanol (Sulieman et al., 2013).

Sucrose is broken down using fermentation and 14 enzymes with the water to two types of simple sugars (glucose and fructose). The glucose and fructose converted to ethanol by anaerobic fermentation can be represented by the following equation (Williamson et al., 2007). The Sukkari dates contain a total sugar content of $67.42 \%$, which can be divided into four types of fructose $19.8 \%$, glucose $14.96 \%$, sucrose $29.9 \%$, and maltose $3.57 \%$. The Khlass dates contain a total sugar content of $62.2 \%$, divided into four types of fructose $34.97 \%$ and glucose $31.94 \%$ sucrose $0.1 \%$ and maltose $0.1 \%$ (Bhat and Sapna, 2003; Nanda, et al., 2003; Ouchemoukh et al., 2010; Hassan et al., 2014; Elamshity, 2014). The Berhi dates contain a total sugar content of $57.6 \%$, divided into two types of fructose $27.6 \%$ and glucose $29.7 \%$ (Ahmed et al., 1995). This study aims to investigate the effect of anaerobic fermentation temperature on the production of ethanol fuel from three different types of sugar compositions in dates that commonly produced in Saudi Arabia.

\section{MATERIALS AND METHODS}

\section{Materials}

1 - Three different types of Saudi date residues (Sukkari, Khlass, and Berhi) from the King Saud University Farm in Drab were utilized during this research work. These residues are commonly used as animal feeds. The moisture content of date residues is from 10 to $12 \%$ (w.b.).

2 - Nine glass fermenters were used with a fermented capacity of $2.5 \mathrm{~L}$, containing a stirrer of stainless steel.

3 - Three similar water basins of stainless steel, each one comprising three glass fermenters. The water basin was function for heating the fermenters according to the desired level of fermentation temperature as shown in Fig (1).

4 - Device (ABBE 5 Refractometer, Bellingham \& Stanley Ltd., Tun-bridge Wells UK) for measuring sugar contained.

5 - The bakery yeast (Saccharomyces cerevisiae yeast) was used during the fermentation experiments.

Total soluble solids (TSS)

Total soluble solids content in all treatments were determined before and after the fermentation processes using an Atago digital refractometer (Tokyo, Japan) which has a scale ranged between 0 and $30 \%$ Brix unit.

\section{Sugar extraction of dates (syrup)}

The sugars were extracted from the dates using distilled water at a rate of $1: 2.5(\mathrm{w} / \mathrm{v})$ of total dry dates, at $40{ }^{\circ} \mathrm{C}$ for four hours to prepare the syrup necessary for testing. The fiber and lingering material were removed using a set of filters to obtain pure syrup. The sugar content of the syrup was estimated to be approximately $23 \%, 23 \%$, and $20 \%$ in Sukkari, Khlass, and Berhi, respectively. The required amount of water to adjust the total sugar in the solution to be $20 \%$ was calculated using the following formula (Liu and Chen, 1981):

Where: $\mathrm{Y}=$ dilution volume (liter)

$\mathrm{X}=$ amount of raw material added $(\mathrm{kg})$

Ts1 = total solid of raw material (sugar in solution)

Ts2 = total solid of fermentation material.

Preparation of yeast environment,

Fast-fermentation yeast which commonly used in bakeries (Wild strain Saccharomyces cerevisiae yeast, STAR brand), wheat flour, molasses has a concentration of $70 \%$, and dates juice has $20 \%$ sugar, ( 3 g yeast, $3 \mathrm{~g}$ wheat flour, and $8 \mathrm{~g}$ molasses, and $15 \mathrm{~g}$ dates juice) were used for each liter of distilled water. The sterilization of the fermentation environment was carried out in an autoclave at temperature of $121^{\circ} \mathrm{C}$ for 15 minutes. Two grams of fast-fermentation yeast (Saccharomyces Cerevisiae) was added to $500 \mathrm{~g}$ of the fermentation environment, and were poured in fermented at a capacity of 2 -liter (anaerobic fermentation with flipping at; 120 $\mathrm{rpm}, 15 \mathrm{~min}$. each $2 \mathrm{~h}$ for $24 \mathrm{~h}$ at $35^{\circ} \mathrm{C}$ ).

Methods

\section{Fermentation process}

The experiments were executed by adding $50 \mathrm{ml}$ of the activated yeast environment per liter of juice and placing it in a glass fermenter with 2.5-liter fermentation capacity. The glass fermenters were placed in a water basin to control the fermentation temperatures under study $\left(30,35\right.$ and $\left.40^{\circ} \mathrm{C}\right)$. 


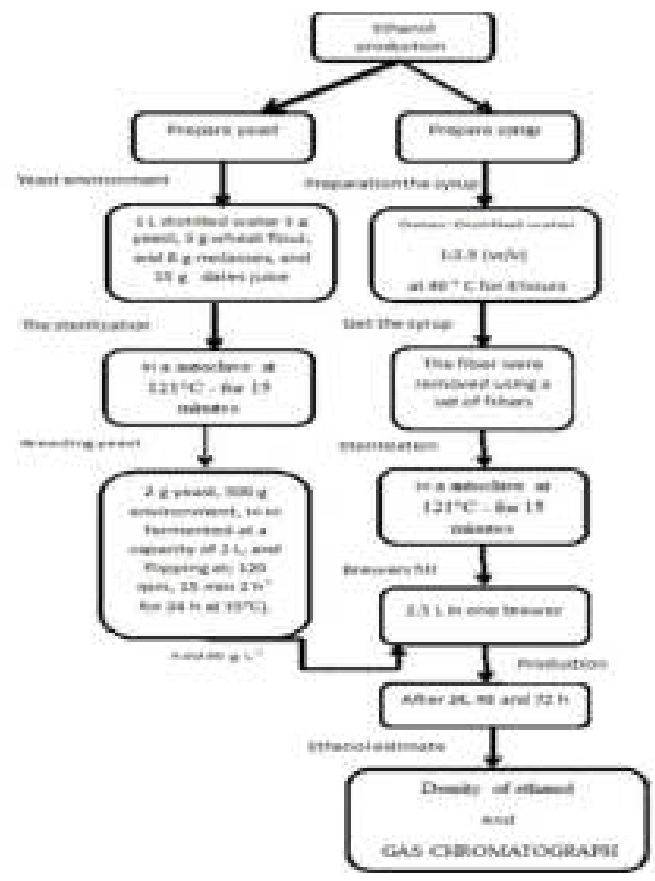

(a)

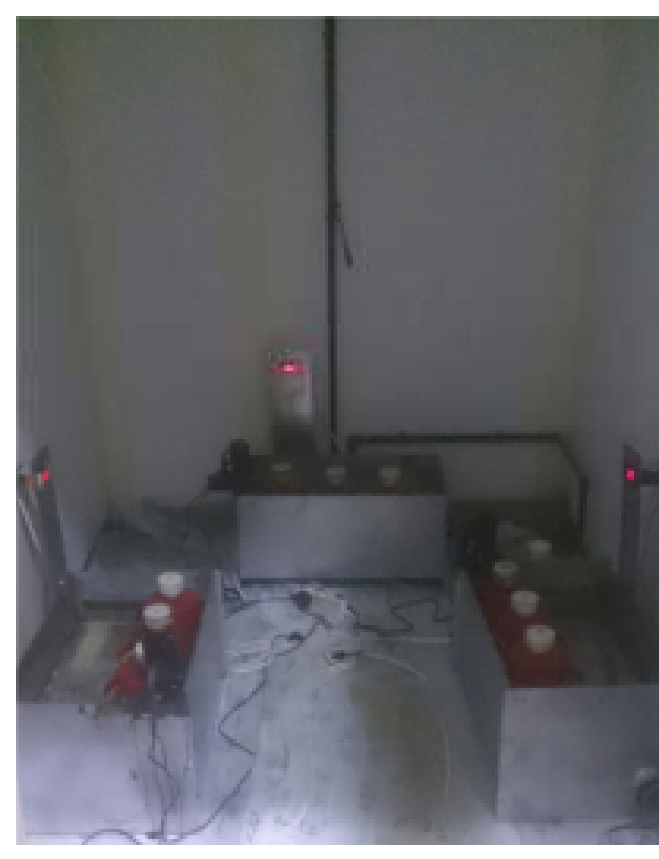

(b)

Fig .1. (a): Diagram of ethanol production process and (b) image of brewers

\section{Estimation of Ethanol}

Ethanol concentration was separated using two methods:

1- The density of ethanol is 0.78 g.cm ${ }^{-3}$ at $100 \%$ concentration and temperature of $25^{\circ} \mathrm{C}$, while it was 0.8 g.cm ${ }^{-3}$ at $96 \%$ concentration and temperature of $25^{\circ} \mathrm{C}$

2 - Using a device estimating the concentration of ethanol (GAS CHROMATOGRAPH - GC - 2025 SHIMADZU - Japan)

Statistical analysis:

Data was analyzed for multiple comparisons by analysis of variance with least significant differences (LSD) between means at 5\% significance level using SAS 9.2 software (SAS Institute, Cary, NC).

\section{RESULTS AND DISCUSSION}

The most important requirements for the anaerobic fermentation process were the yeast Saccharomyces used to produce ethanol, the presence of carbon, nitrogen, and basic minerals. Dates are an important source of all these

Table 1. Average ethanol production of three different species of dates under three different levels of fermentation temperatures

\begin{tabular}{|c|c|c|c|c|c|c|c|c|}
\hline \multicolumn{3}{|c|}{ Sukkari } & \multicolumn{3}{|c|}{ Khlass } & \multicolumn{3}{|c|}{ Berhi } \\
\hline $\begin{array}{l}\text { Ethanol\%, } \\
\text { (v/v) }\end{array}$ & $\begin{array}{c}{ }^{1} \text { Concentrate of } \\
\text { sugar }\end{array}$ & $\begin{array}{l}{ }^{2} \text { Sugar } \\
\text { ratio\% } \%\end{array}$ & $\begin{array}{c}\text { Ethanol\%, } \\
(\mathrm{v} / \mathrm{v})\end{array}$ & $\begin{array}{c}\text { Concentrate } \\
\text { of sugar }\end{array}$ & $\begin{array}{l}\text { Sugar } \\
\text { ratio\% } \%\end{array}$ & $\begin{array}{c}\text { Ethanol\%, } \\
(\mathrm{v} / \mathrm{v})\end{array}$ & $\begin{array}{c}\text { Concentrate of } \\
\text { sugar }\end{array}$ & $\begin{array}{l}\text { Sugar } \\
\text { ratio\% }\end{array}$ \\
\hline $0^{\mathrm{cdg}}$ & $20^{\text {Aae }}$ & $0^{\mathrm{Cdg}}$ & $0^{\text {cdf }}$ & $20^{\text {Aat }}$ & $0^{\text {Cdf }}$ & $0^{\text {cde }}$ & $20^{\text {Aag }}$ & $0^{\mathrm{cde}}$ \\
\hline $5.33^{\mathrm{Ccg}}$ & $16.6^{\mathrm{Abe}}$ & $17^{\mathrm{Ccg}}$ & $5.46^{\mathrm{cct}}$ & $16.3^{\mathrm{Abf}}$ & $18.1^{\mathrm{cct}}$ & $6.7^{\text {c ce }}$ & $16.5^{\mathrm{Abg}}$ & $17.5^{\text {c ce }}$ \\
\hline $8.6^{\mathrm{Cbg}}$ & $14.36^{\text {Ace }}$ & $28.2^{\mathrm{Cbg}}$ & $8.83^{\mathrm{Cbt}}$ & $14.14^{\text {Act }}$ & $29.3^{\mathrm{cbt}}$ & $10.7^{\text {Cbe }}$ & $14^{\mathrm{Acg}}$ & $30^{\text {Cbe }}$ \\
\hline $10.76^{\mathrm{Cag}}$ & $13.7^{\text {Ade }}$ & $31.5^{\mathrm{Cag}}$ & $11.1^{\text {Cat }}$ & $12.6^{\text {Adf }}$ & $36.8^{\mathrm{Cat}}$ & $12.1^{\text {Cae }}$ & $12.8^{\text {Adg }}$ & $36^{\mathrm{Cae}}$ \\
\hline $0^{\text {Adg }}$ & $20^{\mathrm{Cae}}$ & $0^{\text {Adg }}$ & $0^{\text {Adf }}$ & $20^{\text {Caf }}$ & $0^{\text {Adf }}$ & $0^{\text {Ade }}$ & $20^{\text {Cag }}$ & $0^{\text {Ade }}$ \\
\hline $5.96^{\text {Acg }}$ & $15.66^{\mathrm{Cbe}}$ & $21.7^{\text {Acg }}$ & $6.6^{\text {Act }}$ & $15.6^{\mathrm{cbt}}$ & $21.8^{\text {Act }}$ & $6.8^{\text {Ace }}$ & $15^{\mathrm{Cbg}}$ & $25^{\text {Ace }}$ \\
\hline $9.26^{\mathrm{Abg}}$ & $13.76^{\text {cce }}$ & $31.2^{\mathrm{Abg}}$ & $9.3^{\mathrm{Abt}}$ & $13.8^{\mathrm{Cct}}$ & $30.7^{\mathrm{Abt}}$ & $13.4^{\mathrm{Abe}}$ & $12^{\operatorname{lcg}}$ & $40^{\mathrm{Abe}}$ \\
\hline $12.33^{\mathrm{Aag}}$ & $12.03^{\mathrm{Cde}}$ & $39.85^{\mathrm{Aag}}$ & $12.2^{\text {Aaf }}$ & $11.9^{\mathrm{Cdf}}$ & $40.3^{\mathrm{Aaf}}$ & $13.6^{\text {Aae }}$ & $10.5^{\mathrm{Cdg}}$ & $47.5^{\mathrm{Aae}}$ \\
\hline $0^{\mathrm{Bdg}}$ & $20^{\text {Bae }}$ & $0^{\mathrm{Bdg}}$ & $0^{\text {Bdf }}$ & $20^{\mathrm{Bdf}}$ & $0^{\text {Baf }}$ & $0^{\text {Bde }}$ & $20^{\mathrm{Bag}}$ & $0^{\mathrm{Bde}}$ \\
\hline $6.4^{\mathrm{Bcg}}$ & $15.5^{\text {Bbe }}$ & $22^{\mathrm{Bcg}}$ & $6.7^{\mathrm{Bcf}}$ & $15.5^{\mathrm{Bbf}}$ & $22.3^{\mathrm{Bcf}}$ & $6.9^{\text {Bce }}$ & $15^{\mathrm{Bbg}}$ & $25^{\text {Bce }}$ \\
\hline $8.23^{\mathrm{Bbg}}$ & $14.56^{\text {Bce }}$ & $27.2^{\mathrm{Bbg}}$ & $9.85^{\mathrm{Bbf}}$ & $13.5^{\mathrm{Bcf}}$ & $32.5^{\mathrm{Bbf}}$ & $13.6^{\mathrm{Bbe}}$ & $13.4^{\mathrm{Bcg}}$ & $33^{\text {Bbe }}$ \\
\hline $9.66^{\mathrm{Bag}}$ & $14.13^{\text {Bde }}$ & $29.35^{\mathrm{Bag}}$ & $12.8^{\mathrm{Baf}}$ & $11.5^{\text {Bat }}$ & $42.3^{\mathrm{Bdt}}$ & $13.6^{\mathrm{Bae}}$ & $11.3^{\mathrm{Bdg}}$ & $43.5^{\mathrm{Bae}}$ \\
\hline
\end{tabular}

"Same upper letter (A,B and C) in column means no significant difference in temperature treatment, same lower letter (a,b,c and d) in column means no significant difference in time treatment and same lower letter (e,f and $g$ ) in raw means no significant difference in type of dates treatment. 'Concentration of sugar in the dates juice during the fermentation process. ${ }^{2}$ The percentage of sugars converted during fermentations is attributed, to the ratio of primary sugars in date juice elements along the high sugar content. The fermentation temperature is one of the most important factors affecting production of ethanol from dates.

Effect of temperature on ethanol production

Ethanol production from the fermentation of three types of dates (Sukkari, Khlass, and Berhi) was measured at different fermentation times $(24,48$, and 72 hours). The concentration of sugar was $20 \%$, at three levels different levels of fermentation temperatures $30^{\circ} \mathrm{C}$, $35^{\circ} \mathrm{C}$, and $40^{\circ} \mathrm{C}$. Table (1) lists the average ratio of ethanol production under different temperature levels. Figs (2), (3), and (4) refer the effect of fermentation temperatures on ethanol production. Fig (2) shows the increase in ethanol production with high temperature under $24 \mathrm{~h}$ fermentation time. The ethanol production of dates (Sukkari) was on an average (v/v) 5.33\%, 5.96\%, and $6.4 \%$, at 30,35 , and $40^{\circ} \mathrm{C}$, respectively, whilst, it was on an average for the dates (Khlass) (v/v) $5.46 \%, 6.6 \%$ and $6.7 \%$ at the same temperature levels. 
The ethanol production of dates (Berhi) was (v/v) $6.7 \%, 6.8 \%$ and $6.9 \%$ at 30,35 , and $40^{\circ} \mathrm{C}$, respectively. The ethanol production under fermentation time of $48 \mathrm{~h}$ is shown in Fig (3). It is referred that, the ethanol production of dates (Sukkari) was (v/v), 8.6\% 9.26\% and $8.23 \%$ at 30,35 and $40^{\circ} \mathrm{C}$, respectively. While, the ethanol production of dates (Khlass) was $8.83 \%(\mathrm{v} / \mathrm{v}), 9.3 \%(\mathrm{v} / \mathrm{v})$, and $9.85 \%(\mathrm{v} / \mathrm{v})$, at the same temperature levels of fermentation. The average ethanol production for dates (Berhi) was (v/v) $10.70 \%$, $13.40 \%$, and $13.60 \%$ at 30,35 , and $40^{\circ} \mathrm{C}$, respectively. Fig (4) shows the ethanol production under fermentation time of $72 \mathrm{~h}$. Under this circumstances the ethanol production of dates (Sukkari) was on an average (v/v) 10.\%, 12.33\%, and $9.66 \%$ at fermentation times of 30,35 , and $40^{\circ} \mathrm{C}$, respectively, while, the ethanol production of dates (Khlass) was on an average (v/v) $11.13 \%, 12.2 \%$ and $12.8 \%$ at the same temperature levels. But it was for the dates (Berhi) on an average (v/v) $12.10 \%, 13.60 \%$ and $13.60 \%$ at the same levels of fermentation temperature.

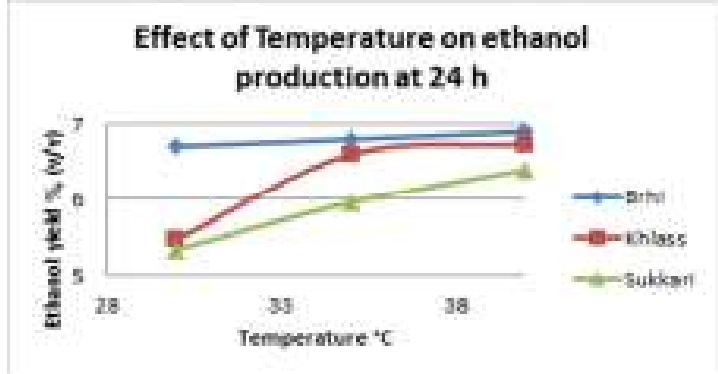

Fig. 2. Ethanol production for three different species of dates at three different fermentation temperatures and fermentation time of $24 \mathrm{~h}$.

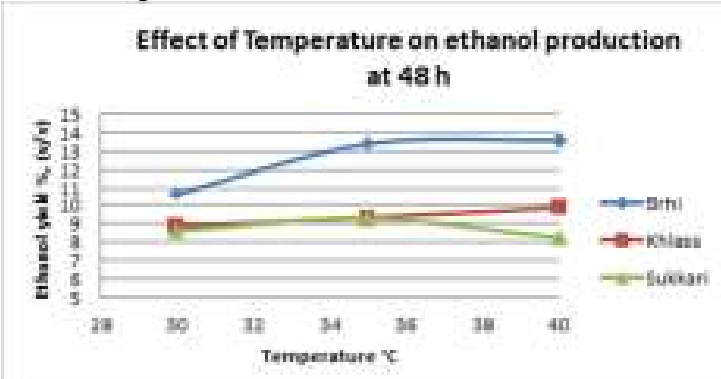

Fig 3. Ethanol production for three different species of dates at three different fermentation temperatures and fermentation time of $\mathbf{4 8 h}$.

Effect of Temperature on ethanol production at

$72 \mathrm{~h}$

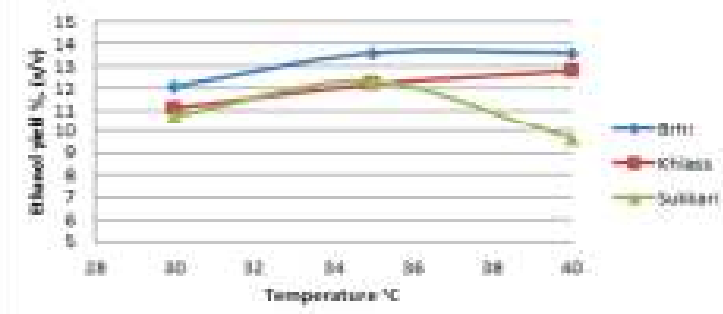

Fig 4. Ethanol production for three different species of dates at three different fermentation temperatures and fermentation time of $72 \mathrm{~h}$.

The obtained results referred that increasing the fermentation times from $24 \mathrm{~h}$ to $72 \mathrm{~h}$ resulting in increasing the rate of ethanol production of Sukkari at fermentation temperature of $35^{\circ} \mathrm{C}$ by $55.37 \%$ and $106.88 \%$ as compared with $48 \mathrm{~h}$ and $72 \mathrm{~h}$ of fermentation time, respectively. The effect of the fermentation time on the production of ethanol at three different fermentation temperatures is shown in Figs (5), (6), (7). The ethanol production is usually increased with increasing the hydraulic retention time under all fermentation temperatures. The highest of ethanol production was achieved at hydraulic retention time (HRT) $72 \mathrm{~h}$ and fermentation temperature of $35^{\circ} \mathrm{C}$ for Sukkari and Berhi, whilst it was achieved at $40^{\circ} \mathrm{C}$ for khlass.

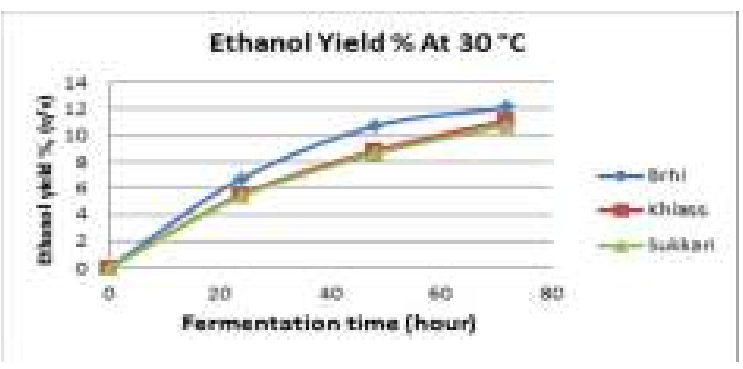

Fig 5. Ethanol production under different fermentation times and fermentation temperature of $30^{\circ} \mathrm{C}$.

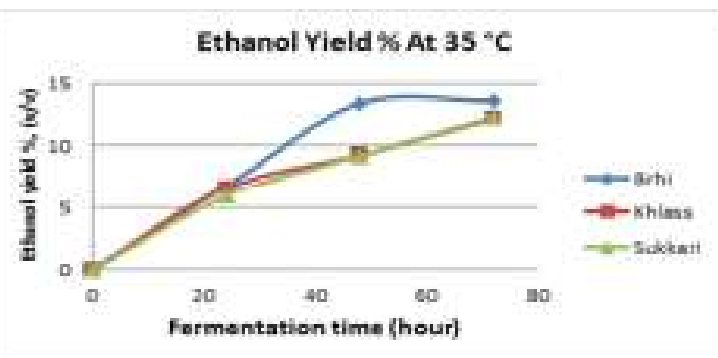

Fig 6. Ethanol production under different fermentation times and fermentation temperature of $35^{\circ} \mathrm{C}$

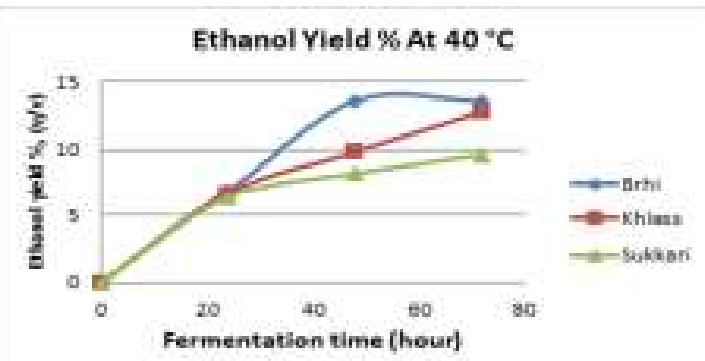

Fig 7. Ethanol production under different fermentation times and fermentation temperature of $40^{\circ} \mathrm{C}$.

Effect of fermentation temperature on sugar consumption Sugar consumption for the three different types of dates(Sukkari, Khlass, and Berhi) was measured at different fermentation times $(24,48$, and 72 hours). The concentration of sugars was $20 \%$, for the three different fermentation temperatures $\left(30,35\right.$, and $\left.40^{\circ} \mathrm{C}\right)$. The effect of fermentation temperature on sugar consumptions are plotted in Figs (8), (9), and (10). Fig (8) refers an increase in sugar consumption with high level of temperature during the first fermentation time $(24 \mathrm{~h})$. For the duration of this experiment, the average sugar consumption of dates (Sukkari) was 17\%, $21.7 \%$, and $22.3 \%$ of total sugars at fermentation temperature of 30,35 , and $40^{\circ} \mathrm{C}$, respectively. While, the average sugar consumption of dates (Khlass) was $18.1 \%$, 
$21.8 \%$, and $22.3 \%$ of total sugar at the same temperature levels, respectively. The sugar consumptions of dates (Berhi) was $17.5 \%, 25 \%$, and $25 \%$ of total sugar at 30,35 , and $40^{\circ} \mathrm{C}$, respectively. The sugar Consumptions for the fermentation time of 48 hours is shown in Fig (9). During this experiment the average sugar consumption of dates (Sukkari) was $28.2 \%, 31.2 \%$, and $27.2 \%$ of the total sugar under three different fermentation temperatures of 30 , 35 and, $40^{\circ} \mathrm{C}$. While, the average sugar consumption of dates (Khlass) was $23.9 \%, 30.7 \%$, and $32.5 \%$ of the total sugar under the same temperature levels, respectively. The average sugar consumption of dates (Berhi) was 30\%, 40\%, and $33 \%$ of the total sugar under three different fermentation temperature levels, respectively. Fig (10) shows sugar consumption at fermentation time of 72 hours. The average sugar consumption for dates (Sukkari) was 31.5\%, 39.85\%, and $29.35 \%$ of the total sugar at three different fermentation temperature levels, respectively. While, the average sugar consumption for dates (Khlass) was 36.8\%, 40.3\%, and $42.3 \%$ of the total sugar at the same fermentation temperature levels, respectively. The average sugar consumption for dates (Berhi) was $36 \%, 47.5 \%$, and 43.5 $\%$ of the total sugar under the same fermentation temperature levels, respectively.

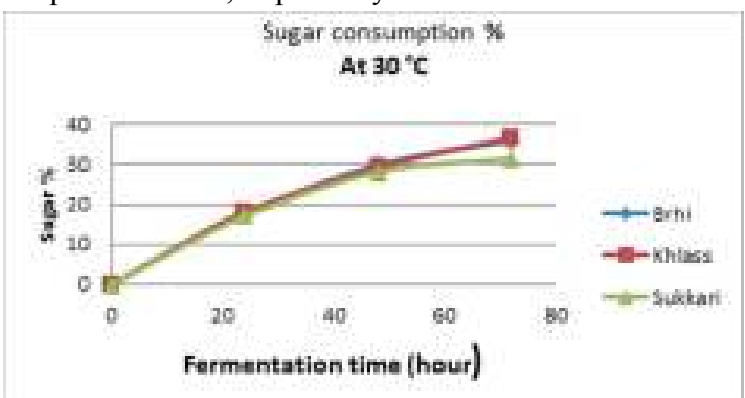

Fig 8. Sugar consumption versus fermentation time under fermentation temperature of $30^{\circ} \mathrm{C}$.

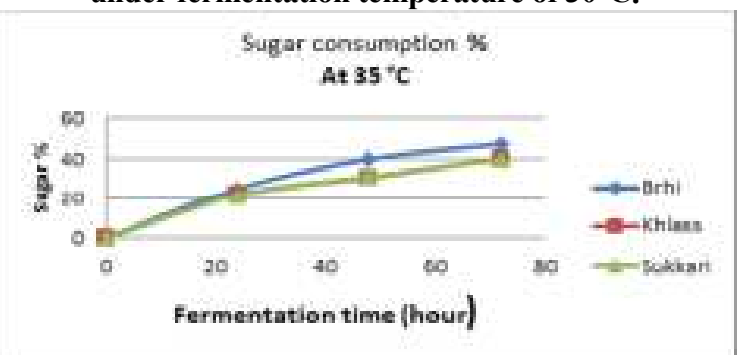

Fig 9. Sugar consumption versus hydraulic retention time under fermentation temperature of $35^{\circ} \mathrm{C}$.

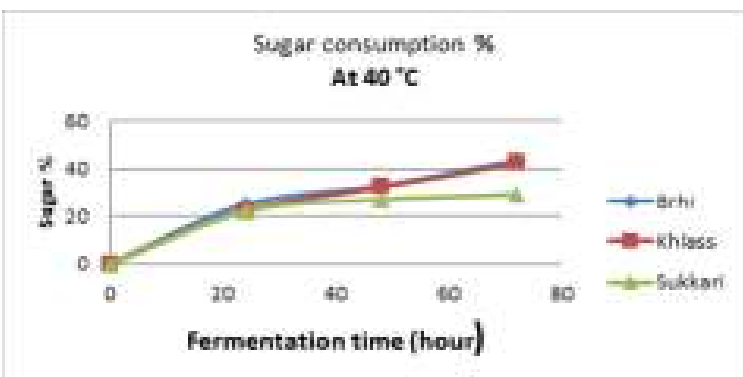

Fig 10. Sugar consumption versus hydraulic retention time under fermentation temperature of $40^{\circ} \mathrm{C}$.

The effect of fermentation times on the sugar consumption at different temperatures is shown in Figs (11), (12), and (13). They clearly referred that the sugar consumptions increase as the fermentation time increases under all fermentation temperatures. They also referred that, the highest rate of sugar consumptions was achieved during the fermentation time of 72 hours at fermentation temperatures of $35^{\circ} \mathrm{C}$ for Sukarri dates, $40^{\circ} \mathrm{C}$ for Khlass and Berhi.

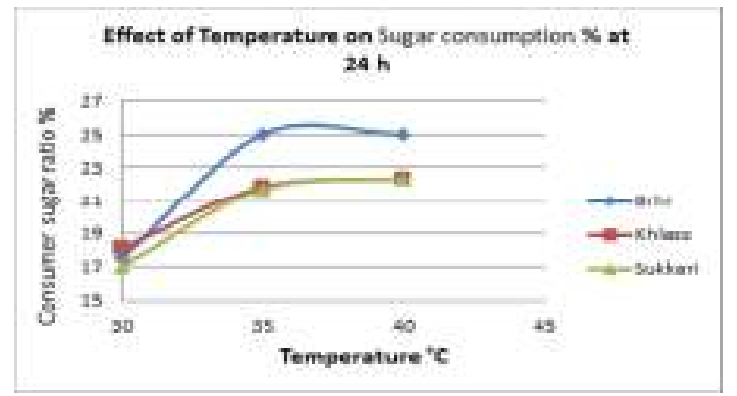

Fig 11. Effect of fermentation temperature on sugar consumption with fermentation time of $24 \mathrm{~h}$.

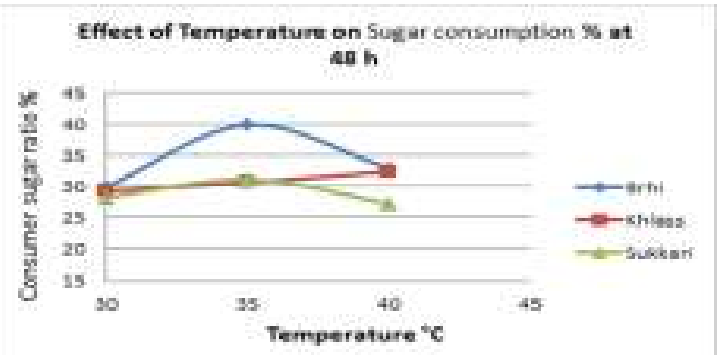

Fig 12. Effect of fermentation temperature on sugar consumption with fermentation time of $48 \mathrm{~h}$.

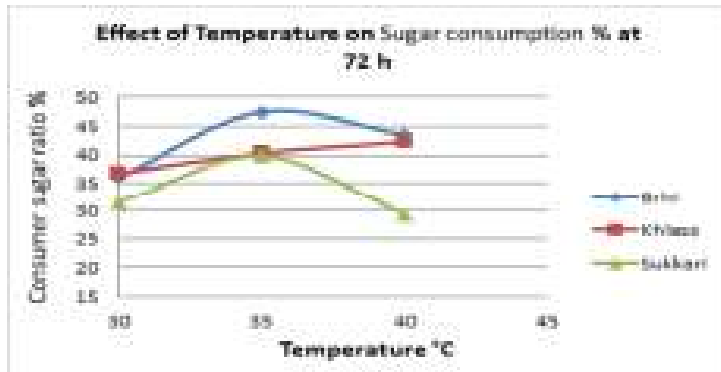

Fig 13. Effect of fermentation temperature on sugar consumption with fermentation time of $72 \mathbf{h}$.

Effect of fermentation temperature on ethanol production The productivity of ethanol fuel $\left(\mathrm{cm}^{3} \mathrm{~kg}^{-1}\right.$ dates $)$ is summarized and listed in Table (2) and plotted in Fig (14). The productivity of ethanol for the three different dates species (Sukkari, Khlass, and Berhi) at fermentation temperature of $30^{\circ} \mathrm{C}$ and fermentation time of 24-hour was on an average 153.3, 157.16, and $167.5 \mathrm{~cm}^{3} \mathrm{~kg}^{-1}$ dates, respectively. While, the productivity of ethanol at fermentation temperature of $30^{\circ} \mathrm{C}$ and fermentation time of 48-hour was 247.2, 253.9, and267.5 $\mathrm{cm}^{3} \mathrm{~kg}^{-1}$ dates, respectively. Finally, the productivity of ethanol at fermentation temperature of $30^{\circ} \mathrm{C}$ and fermentation time of 72-hour was 309.4, 320.1, and $302.5 \mathrm{~cm}^{3} \mathrm{~kg}^{-1}$ dates, respectively. On the other hand, the productivity of ethanol for the three different dates species (Sukkari, Khlass, and Berhi) at fermentation temperature of $35^{\circ} \mathrm{C}$ and fermentation 
time of 24-hour was on an average 171.4, 189.75, and 170 $\mathrm{cm}^{3} \mathrm{~kg}^{-1}$ dates, respectively. While, the productivity of ethanol at fermentation temperature of $35^{\circ} \mathrm{C}$ and fermentation time of 48-hour was 266.5, 267.4, and $336 \mathrm{~cm}^{3}$ $\mathrm{kg}^{-1}$ dates, respectively. Finally, the productivity of ethanol at fermentation temperature of $35^{\circ} \mathrm{C}$ and fermentation time of 72-hour was $354.5,350.8$, and $340 \mathrm{~cm}^{3} \mathrm{~kg}^{-1}$ dates, respectively.

Table 2. Productivity of ethanol fuel $\left(\mathrm{cm}^{3} \mathrm{~kg}^{-1}\right.$ date) form three different species of dates..

\begin{tabular}{ccccc} 
Temperature, ${ }^{\circ} \mathbf{C}$ & Time, h & Sukkari & Khlass & Berhi \\
\hline \multirow{3}{*}{30} & 0 & 0.0 & 0.0 & 0.0 \\
& 24 & 153.2 & 157.2 & 167.5 \\
& 48 & 247.3 & 254.0 & 267.5 \\
& 72 & 309.4 & 320.1 & 302.5 \\
35 & 0 & 0.0 & 0.0 & 0.0 \\
& 24 & 171.4 & 189.8 & 170.0 \\
& 48 & 266.2 & 267.4 & 335.0 \\
40 & 0 & 354.5 & 350.8 & 340.0 \\
& 24 & 0.0 & 0.0 & 0.0 \\
& 48 & 236.0 & 193.6 & 172.5 \\
& 72 & 277.7 & 283.2 & 340.0 \\
& & 368.0 & 340.0 \\
\hline
\end{tabular}

From the previous results, the heating process of dates juice during an anaerobic fermentation resulting in increasing the productivity of ethanol fuel from species; Sukkari by $5.33 \%$ and $12.33 \%$, from Khlass dates by $5.5 \%$ and $12.8 \%$ and from Berhi dates by $6.7 \%$ and $13.6 \%$ due to change in fermentation time and fermentation temperatures. The obtained results also referred that the productivity of ethanol is directly proportional to the glucose and fructose in raw material. These data are in agreement with the data published by (Ahmed et al., 1995; Bhat and Sapna, 2003; Nanda et al., 2003; Williamson et al., 2007; Ouchemoukh et al., 2010 ; Sulieman et al., 2013; Elamshity, 2014; Hassan et al., 2014).

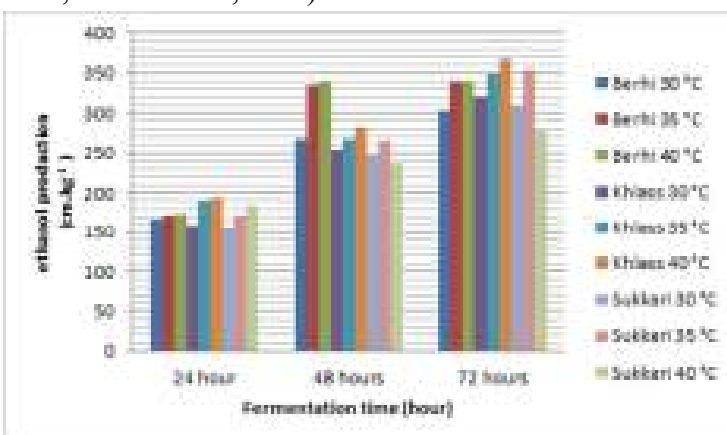

Fig 14. Productivity of ethanol $\left(\mathrm{cm}^{3} \mathrm{~kg}^{-1}\right.$ date $)$ at three different fermentation temperatures and fermentation times.

\section{CONCLUSION}

Sugars in Low-grade dates are mainly based on glucose and fructose, which can be converted into ethanol and can also serve as the main sources of carbohydrate for yeast growth. Other nutrients, minerals and vitamins are also presented in the dates components that promote fermentation to produce bioethanol. The most important factors affecting ethanol production are associated with; the initial sugar concentrations, fermentation temperatures and fermentation time. The ethanol yield greater than $300 \mathrm{~cm}^{3}$ ethanol per one $\mathrm{kg}$ of dates was achieved during the experimental work. The productivity of ethanol $(\mathrm{v} / \mathrm{v})$ at three different fermentation temperatures $\left(30,35\right.$ and $40^{\circ} \mathrm{C}$ ) from juice of Sukkari date, respectively, was $10.76,12.33$ and $9.66 \%$. While the productivity of ethanol (v/v) from juice of Khlass at the same fermentation temperatures was $11.1,12.2$ and $12.8 \%$, respectively. Whilst, the productivity of ethanol (v/v) from juice of Berhi at the same fermentation temperatures was12.1, 13.6 and $13.6 \%$, respectively. Further experimental work are needed for more studying on the technology of bioethanol production using different sugars ratio and other types of yeasts that may enhance the ethanol revenues.

\section{ACKNOWLEDGEMENT}

The authors are grateful to the Deanship of Scientific Research, King Saud University for funding through the Vice Deanship of Scientific Research Chairs.

\section{REFERENCES}

Abdel-Banat, B.M.; Hoshida, H. A.; Ano, S. N, and Akada, R. (2010) "High-temperature fermentation: how can processes for ethanol production at high temperatures become superior to the traditional process using mesophilic yeast?" Appl. Microb. Biotech., 85 (4): 861 - 867.

Ahmed, I. A.; Ahmed, A. W. K.; and Robinson, R. K. (1995) "Chemical composition of date varieties influenced by the stage of ripening, Food Chem., 54, 305-309.

Amorim, H.; Basso, L.; and Lopes, M. (2009) "Sugar cane juice and molasses, beet molasses and sweet sorghum: composition and usage" The Alcohol Textbook, $5^{\text {th }}$ Edition. W.M. Ingledew, G.D. Austin, C. Kluhspies and D.R. Kelsall, Eds., Nottingham University Press: Nottingham, p. $39-46$.

Asli, M. S. (2010) "A study on some efficient parameters in batch fermentation of ethanol using Saccharomyces cerevesiae SC1 extracted from fermented siahe sardasht pomace" African J. Biotech., 9(20).

Basso, L.C.; Basso, T.O.; and Rocha, S. N. (2011) "Ethanol production in Brazil: the industrial process and its impact on yeast fermentation" Biofuel productionrecent developments and prospects. Rijeka, $85-100$.

Benarji, D. S. N. and Ayyanna, C. (2016) "Statistical Optimizations of Fermentation Factors on Bioethanol Production from Mahua Flower (Madhuca indica) with Saccharomyces cerevisiae by Response Surface Methodology in Batch Bioreactor" Microbioz Jouranls, J. Microbiol. Biomed. Res. 2 (1)

Besbes, S.; Drira, L.; Blecher, C.; Deronne, C.; and Attia, H. (2009) "Adding value to hard date (Pheonixdactylifera L.): Compositional, functional and sensory characteristics of date jam" Food Chem. 112: $406-411$.

Bhat, K. K. and Sapna V. K. (2003) "Sensory properties, physical and chemical samples of commercial honey" Food Research International, Sensory Science Department, Central Food Technological Research Institute, Mysore-570 013, India, 36 (2): 183 - 191

Bollók, M.; Réczey, K.; and Zacchi, G. (2000) "Simultaneous saccharification and fermentation of steam-pretreated spruce to ethanol" in Twenty-First Symposium on Biotechnology for Fuels and Chemicals, Springer

Demirbas, A. (2007) "Progress and recent trends in biofuels" Progress in Energy and Combustion Sciences, 33 (1): $1-18$.

Edgardo, A. P.; Carolina, R.; Manuel, F. J.; and Baeza, J. (2008) "Selection of thermos-tolerant yeast strains $<$ I $>$ Saccharomyces cerevisiae $</$ I $>$ for bioethanol production" Enzyme Microblog. Technology, 43 (2): $120-123$.

Elamshity, M. G. K. (2014) "Development of a Nutritional Drink from Cow's and Camel's Milk with Date Syrup" Department of Agricultural Engineering, Faculty of Food and Agricultural Sciences, King Saud University, Riyadh, Saudi Arabia. 
Elleuch, M.; Besbes, S.; Roiseux, O.; Blecher, C.; Deroanne, C.; Dirar, N.; and Attia, H. (2008) "Date flesh: Chemical composition and characteristics of the dietary fiber, Food Chem... 111: 676-682.

Fakruddin, MIslam, ;; M. A.; Ahmed, M. M.; and Chowdhury, N. (2013) "Process optimization of bioethanol production by stress tolerant yeasts isolated from agro-industrial waste" Int. J. Renew. Sustain. Energy, 2(4)

Ghanim, A. N. (2013) "Bioethanol Production from Iraqi Date Palm Resources" J. Babylon University/ Eng. Sci. 1 (21): $13-20$

Ghassem, T.; Sadat, D. A.; and Kulkarni, D. (2012) "Optimization of yeast for ethanol production" Int. J. Res. Ayurveda Pharm, 3(1): 95 - 97.

Goksungur, Y.A. Z. N. (2001) "Production of Ethanol from Beet Molasses by Ca-Alginate Immobilized Yeast Cells in a Packed-Bed Bioreactor, Turk J. Biol, 265 275.

Gorsek, A. and Zajsek, K. (2010) "Influence of temperature variations on ethanol production by kefir grainsmathematical model development" Chemical Engineering 20

Hagerdal, H. B.; Galbe, M.; M. F.; Gorwa-Grauslund, G. L.; and Zacchi, G. (2006) "Bio-ethanol-the fuel of tomorrow from the residues of today" Trends Biotechnology, 24 (12): 549 - 556.

Hassan, B. H.; Mohammed, A. A.; Khaled A.; and Ahmed, M. (2014) "Moisture sorption isotherms and hot air drying characteristics of Saudi dates (Phoenix dactylifera L.) and the effect of drying on dates color and mechanical properties" Project report, National Plan for Science and Technology. King Saud university project \#10-AGR, 1194 - 1202.

Jones, A.M.; Thomas, K.C.; and Ingledew, W.M. (1994) "Ethanolic fermentation of blackstrap molasses and sugarcane juice using very high gravity technology" J. Agric. Food Chem. 42(5): $1242-1246$

Joshi, S.; Dhopeshwarkar, R.; Jadhav, R; Jadhav, U.; D'Souza, L.; and Dixit, J. (2001) "Continuous ethanol production by fermentation of waste banana peels using flocculating yeast" Indian J. Chem. Technol. 8 (3): 153 - 156 .

Limtong, S.; Sringiew, C.; and Yongmanitchai, W. (2007) "Production of fuel ethanol at high temperature from sugar cane juice by a newly isolated $<$ i $>$ Kluyveromyces marxianus $</ \mathbf{i}>$ " Bio-resource Technol. 98 (17): $3367-3374$.

Lin, Y. and Tanaka, S. (2006) "Ethanol fermentation from biomass resources: current state and prospects" Appl. Microb. Biotech., 69 (6); 627 - 642.

Liu, K.X. and Chen, C.Q. (1981) "Studies on the biogas fermentation of Chinese rural area" Global Impact of Applied Microbiology (GIAMVI). Sixth Int. Conf., 261- 272.

Muttamara, S.; Nirmala, D.; Stuckey, D.C.; and Hamza, A. (1982) "Production of alcohol and acetic acid from pineapple wastes. in International Symposium on Management of Industrial Wastewater in Developing Countries" Pergamon Press
Nanda, V.; Sarkara, B. C.; Sharmaa, H. K.; and Bawab, A.S. (2003) "Physico-chemical properties and estimation of mineral content in honey produced from different plants in Northern India" J. Food Comp. Anal. 16: $613-619$.

Ouchemoukh, S.; Schweitzer, P.; Bey, M. B.; Djoudad-Kadji, H.; and Louaileche, H. (2010) "HPLC sugar profiles of Algerian honeys" Food Chem. 121: 561 - 568

Pinheiro, A. M.; Rocha, G. M.; and Gonçalves, L.B. (2008) "Evaluation of Cashew Apple Juice for the Production of Fuel Ethanol" Appl. Biochem. Biotech., 148: 227 - 234

Pramanik, K. A. R. and Kinetic, D. E. (2005) "Study of ethanol fermentation of grape waste using Saccharomyces cerevisiae yeast isolated from toddy" J. of Inst. Eng., 85: 53 - 58.

Prasad, S.; Anoop Singh, N. J.; and Joshi, H. C. (2007) "Ethanol Production from Sweet Sorghum Syrup for Utilization as Automotive Fuel in India" Division of Environmental Science, Indian Agriculture Research Institute, New Delhi-110012, India, April 4.

Raikar, R. V. (2012) "Enhanced production of ethanol from grape waste" Int. J. Env. Sci., 3(2)

Reddy, L. V. and Reddy, O. (2007) "Production of Ethanol from Mango (Mangifera indica L.) Fruit Juice Fermentation" Res. J. Microbiol.. 2 (10).

Sánchez, S.; Bravo, V.; Moya, A.; Castro, E.; and Camacho, F. (2004) "Influence of temperature on the fermentation of d-xylose by $<\mathrm{i}>$ Pachysolen tannophilus $</ \mathbf{i}>$ to produce ethanol and xylitol" Process Biochem., 39 (6): 673 - 679.

Srinivasarao, B.; Ratnam, B.; Subbarao, S.; Narasimharao, M.; and Ayyanna, C. (2013) "Ethanol production from cashew apple juice using statistical designs" J. Biochem. Microb. Technol., 18 - 15

Sulieman, A. K.; Gaily, M. H.; Zeinelabdeen, M. A.; Putra, M. D.; and Abasaeed, A. E. (June 2013) "Production of Bioethanol Fuel from Low-Grade-Date Extract" International Journal of Chemical Engineering Application, 4 (3)

Vrsalovic, P. A. and Vasic-Racki, D. (2005) "Modeling of the alcohol dehydrogenase production in baker's yeast" Process Biochemistry, 40 (8): 2781 - 2791.

Williamson, K L.; Minard, R.; and Masters, K. M. (2007) "Macroscale and Microscale Organic Experiments" Hougton Mifflin Co., Boston, $5^{\text {th }}$ ed., p 774.

Yah, C.S.; Iyuke, S.E.; Unuabonah, E.I.; Pillay, O.; Vishanta, C.; and Tessa, S. M. (2010) "Temperature optimization for bioethanol production from corn cobs using mixed yeast strains" Online, J. Biolog. Sci., 10 (2): $103-112$

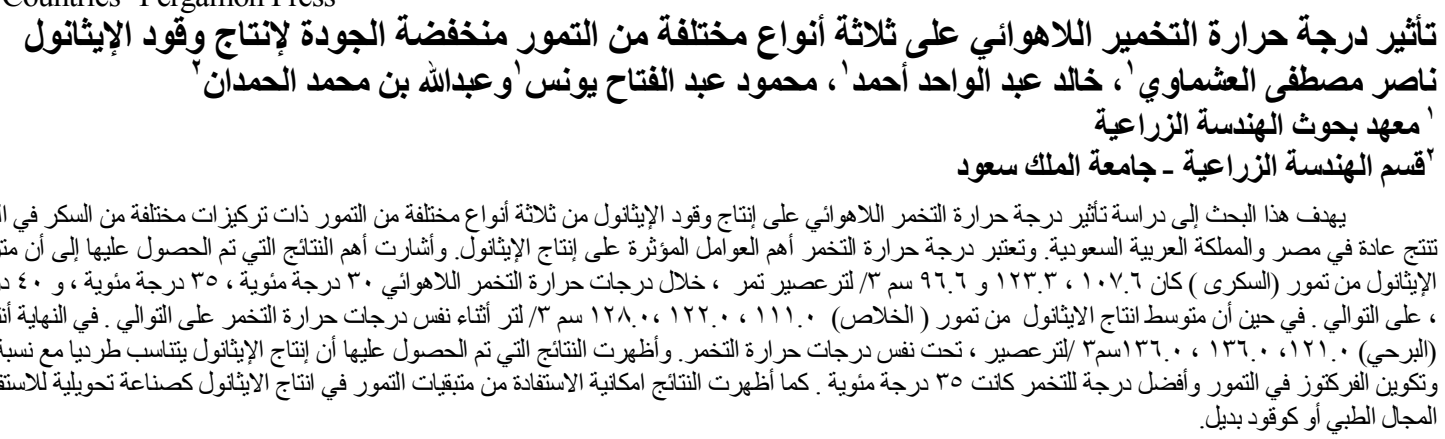

